\title{
No Strings Attached? Challenges and Successes in Creating a Flexible, Wire-free Active Learning Classroom
}

\section{Introduction and Background}

How do you redesign an electronic classroom to allow for best pedagogical practice? Can a learning space be flexible enough to adapt to different teaching methods and class sizes? The librarians at one mid-sized public university dreamed of such a setting--a classroom that was truly free of wires and cords, where every device and piece of furniture could be reconfigured at the point of need (and according to the size of the class). This classroom would accommodate active and cooperative learning and include a robust range of technology including laptop computers, flat screen monitors, and the ability to digitally project images and data around the room--to small groups or to the entire classroom. In 2013, the university librarians at X University obtained a grant to make their dream classroom a reality-attempting to merge the sophisticated technology of a hardwired active learning classroom with the mobile features of a flexible learning space. This article details a three-year implementation process and outlines the logistical and technological opportunities, challenges--even failures--encountered along the way. This experience can serve as a case study for those who are planning their own high-tech teaching spaces.

\section{Review of Literature}

Best practice in higher education instruction emphasizes student-centered learning over traditional lecture-model instruction. This student-centered model includes cooperative and active learning. Cooperative learning, where students work together to solve problems, is "more effective than individualistic methods - pointing again to the power of peers in the learning equation" (Hattie, 2009, 12). Active learning includes various types of student-centered instruction such as problem-based and experiential learning. It is used as an alternative to the traditional lecture method in college classrooms in order to engage students in more meaningful learning experiences (Fink, 2013; Svinicki, 2014). Bonwell and Eison (1991) define active learning as "instructional activities involving students in doing things and thinking about what they are doing" (p. iii).

In 2011, when the librarians in this case study were planning their renovation, many institutions were building classrooms that facilitated active learning, but there was a dearth of literature on the subject. Librarians relied heavily on universities' websites--which featured photos and descriptions of their active learning classroom projects--and an EDUCAUSE report on learning spaces (Obinger, 2006). The leaders in active learning classrooms were primarily in science, technology, engineering, and math (STEM) disciplines; classrooms were designed to provide problem-based and cooperative learning to large classes. Examples include NC State's SCALE-UP (Student-Centered Activities for Large-Enrollment Undergraduate Programs) model (Beichner, 2006), University of Minnesota's Active Learning Classrooms (ALCs) (Brooks and Walker, 2010), and MIT's TEAL (Technology Enabled Active Learning) classroom (Dori and Belcher, 2005), which were designed primarily for science courses. Other classrooms such as the University of Iowa's TILE (Transform, Interact, Learn, Engage) were similar, though they were used by courses in multiple disciplines, which sometimes included library information literacy sessions (Soderdahl, 2010). 
Though each classroom model had its own name and a few distinguishing characteristics, there were many similarities, most of which were modeled after Robert Beichner's SCALE-UP layout or the University of Minnesota's Active Learning Classrooms. Though the University of Minnesota seems to have coined the phrase "active learning classroom," it has been widely adopted as the moniker for classrooms that have the following features:

- Round stationary tables to encourage collaborative work among students. Beichner's model encourages groups of three (2006). In many models, the spaces were designed for very large class sizes.

- Instructor's station in the middle of the room in order to de-emphasize the instructor's role as the only expert in the room. As Nancy Van Note Chism puts it, "spaces must convey co-learning and co-construction of knowledge" $(2006,2.7)$.

- Whiteboards (dry erase boards) on each wall (or on stands) so students could work out problems in groups and share results with one another. Beichner refers to them as "public thinking spaces" $(2006,29.2)$

- Laptops rather than fixed computers.

- Monitors or screens around the room. The SCALE-UP classroom (Beichner, 2006) features two screens on opposite sides of the room, and two projectors are mounted to the ceiling. This arrangement allows students to see a screen from any seat in the classroom. Other classrooms featured large flat screen monitors around the room; these were physically connected to specific tables so groups could share their findings on a single monitor for their group.

- Hardwired technology on the instructor's station and on each round table. Laptops were often used, presumably with wireless capability, but, as pictured on the projects' websites, appeared to be plugged into outlets/units on each table.

- Additional technology pictured or described in these ALCs include microphones so students/faculty can hear each other across large rooms, document cameras to project images to the screens, movable glass marker boards as well as wall whiteboards, and clickers to get responses from the class (Obinger, 2006).

Most of the early active learning classrooms had furniture that was not easily moved and technology that was hardwired to each table, the instructor's station, or to the wall. Because many of these classrooms were designed to serve the needs (and class sizes) of specific science and technology-related courses, departments, and/or disciplines, flexibility may not have been a top priority. In an academic library setting, however, instruction is often provided to a wide range of disciplines and class sizes.

In a recent Project Information Literacy report, Alison Head (2016) reports that when describing "planning and designing academic library space," 50\% of librarians, 77\% of architects, and $40 \%$ of library consultants use the word "flexibility"; $73 \%$ of librarians, $59 \%$ of architects, and 60\% of library consultants use the word "interdisciplinary" (p. 10). These two descriptors followed "collaborative," which was used by all library consultants, $82 \%$ of librarians, and 64\% of architects (Head 2016, p. 10). The idea of more flexibility in the classroom is not a new one. Wireless laptops have been used in classrooms since the mid-1990s, and a white paper written by an architect (Burr, 1971) calls for furniture that is highly adaptable and mobile. Though the early active learning classrooms such as SCALE-UP respond to student learning needs, they do not respond to the need for flexibility. Recently, however, other 
universities that have created their own active learning classrooms have developed sort of a hybrid of an active learning classroom and a place that provides flexible furniture. Researchers at McGill University (2016) developed a Principles of Learning Spaces document, which they aligned with higher education best practices (Finkelstein et al, 2016, p. 30). They make recommendations both for active learning classrooms such as the SCALE-UP or TILE classrooms and "flexible flat classrooms" which feature "lightweight, sturdy wheeled tables and chairs" to allow for "flexibility; students can collaborate in pairs or small groups and use whiteboards" (p. 30). These spaces also feature spacious work surfaces and "ease of movement and comfort in the space" (p. 30).

For flexible learning spaces to be truly flexible, there need to be as few wires as possible. The difficulty arises when attempting to merge the bells and whistles that are hardwired in a traditional active learning classroom like SCALE-UP or the University of Minnesota's ALCs with a more mobile and wire-free area. At the very least, the classroom would need to have wireless access for laptops and devices. Some institutions have been able to install special flooring with built-in data and electrical ports to accommodate any wires needed without anchoring furniture and equipment to the wall (McCullough, 2009).

There are various technologies that allow groups to share screens, brainstorm, and collaborate. Single-display options include interactive whiteboards and interactive tabletops (Baglier and Caswell, 2016; Clayphan et al., 2016). This sophisticated technology can allow multiple students to interact with a large screen via touch and keyboard - and often allow some central control features such as allowing the instructor to send information to a group's table, freeze a screen to get students' attention, display information from one whiteboard/table to a wall-mounted screen, etc. (Clayphan et al., 2016). This technology can be too expensive for many libraries to implement.

There are other methods that allow instructors to project information around the room and for the students to project their own information--either around the room or to members of their group. High-Definition Multimedia Interface (HDMI) cables make this relatively easy to accomplish, but sharing a display wirelessly requires screen mirroring.

Screen mirroring is a regular feature of the Windows operating system with the use of several cable connection options (VGA, DMI, HDMI, and USB). This wired option is available on both desktops and laptops. Anyone who has taken their laptop to present at a conference or classroom has used screen mirroring methods to display their screen on a video projector. Screen mirroring wirelessly to a single TV or display device has also gained popularity in the consumer market, particularly in entertainment - allowing users to project games, videos, and internet content to their home theater systems. Products such as StreamHD's Warpia 120, Google's Chromecast, and WiFi EZCast can wirelessly project a single computer screen to a single TV using an HDTV dongle. Most wireless display technologies are designed for home entertainment (for example, with the right software, AirPlay on an iPhone or other Apple Device can send the display from a device to a large monitor). McGill et al. (2014) explored collaborative screen mirroring in a home entertainment setting; their experiment used cables rather than wireless display technology. They found that shared screen mirroring "significantly improves a small group's ability to collaborate, by enabling device users to pass/take/relinquish the display as required" (MGill et al, 2014, p. 94). Researchers at Dublin City University in Ireland are piloting a system called AirMedia which allows students to "broadcast from their own devices. Up to four devices can be displayed simultaneously" (Gormley et al., 2016, p. 244). 


\section{The Electronic Classroom before the Redesign}

The library's electronic classroom redesign was inspired by two key needs. First, class sizes at the university were growing. Instead of a typical class of 20 to 24 students, classes of 40 students were coming to the library for workshops. In the academic year 2011-2012, 31\% of library instruction sessions had 25 or more students; in the academic year 2012-13, it was $34 \%$. The existing setup, which was designed for 24 students, made it difficult to accommodate classes of this size. Second, and most important, librarians were placing an increased emphasis on studentcentered pedagogical practice, including active and cooperative learning, in their class sessions. Librarians were encouraged to spend less time on demonstration and more time having students participate in finding and thinking about information. Activities, especially group activities, were difficult to conduct in the rigid computer lab-like setting. A room where furniture could easily be moved for activities and groups work — no matter the class size — was ideal to the existing hardwired computer lab setting.

While wireless laptop technology has been available for years, grant monies allowed the librarians to investigate the possibility of creating a truly wire-free classroom. Given the technological innovations in battery charging devices, wireless peripherals, and multi-screen technology in this type of environment, it seemed to be a reasonable goal. The librarians' vision was that all of the equipment in this classroom should be movable to anywhere in the room without having to be connected via wiring. This idea extended beyond the traditional active learning classroom (such as SCALE-UP) to create an active learning environment that would be easily reconfigured for different teaching methods or class sizes. The librarians also wanted to incorporate some of the brainstorming and screen sharing technology of the traditional hardwired active learning classrooms.

\section{Technology}

Before the remodel, the library's electronic classroom held 24 student desktop computers (PCs). The instructor's station held a desktop computer with a 15-inch monitor, a large overhead projector, a VCR, and DVD players, all of which were hardwired to a projector mounted to the ceiling. The PCs were upgraded three times with new CPUs. The classroom also contained a laser printer.

\section{Layout and Furniture}

The library's first electronic classroom, built in 1998, featured six tables that each fit four desktop computers. Small floor ramps were built over the power and networking cords between each table. A large plastic tube attached the power and networking needed to run the devices on the instructor station and connect the station to the projector on the ceiling and the speakers on the wall. The instructor's station was a tall desk with a fixed location in the front right-hand corner of the room. A large freestanding cabinet held various supplies such as microphones, cables, speakers, and paper. Many upgrades to the software and hardware occurred during the intervening years, but the basic layout and function of the hardware and furniture was static. As the technology developed (monitors became wider and thinner; PCs became smaller), much of the built-in features of the tables (troughs for the monitors, square bays under the desk for PCs) became wasted space, and the surface space for students was still limited. 


\section{The Plan for the Active Learning Classroom}

Librarians wanted many of the features of the active learning classrooms such as SCALE-UP, and the campus teaching center provided an opportunity to meet with its creator, Robert Beichner. He encouraged librarians to de-emphasize the instructor's station by purchasing a much smaller station and relocate it to the center of the classroom, redefining the instructor's role from lecturer to more of a coach and guide. Beichner provided specific dimensions for the round tables for group work and suggested that three students at a time could share a laptop. He also suggested installing monitors and whiteboards (dry erase boards) around the room so that small groups can have their own vertical work and sharing space.

As previously noted, many of the example classrooms, including SCALE-UP, were designed for STEM disciplines and for semester-long courses. Librarians had a few unique needs:

1. This classroom is the library's only e-classroom. More than 200 classes are held in this space each academic year. Librarians take turns using the space; the teaching librarians and the library's systems unit shared in any decision making about the classroom, from what software was installed to overall layout of the room.

2. Library instruction is offered to all disciplines on campus. Class sizes, learning outcomes, and instructional methods vary widely.

3. Librarians typically meet with a class once per semester, meaning they have a limited time (50 to 75 minutes) to teach the skills and concepts they have identified for the class. Because of these unique characteristics, librarians wanted as much built-in flexibility in the electronic classroom as possible. Everything needed to be easy to set up, shut down, or change for another class.

The final plan included many features of the SCALE-UP classroom including the round tables, monitors, whiteboards, and the relocation of the instructor's station. Unlike the SCALEUP model, this plan included furniture that was more mobile. For furniture, librarians selected round tables with two half-moon shaped, foldable tables - increasing the possible furniture configurations. All chairs and tables would be on casters to allow librarians to arrange furniture according to both the class size and the appropriate teaching method for each class. Librarians could flip up and move tables out of the way to create more floor space when necessary.

Because the furniture was mobile, all of the technology needed to be mobile as well. This presented a number of questions. The following table presents each question, with the chosen solution. Many flexible learning spaces are set up for students to bring their own devices; because the library in this case was replacing an electronic classroom, librarians wanted to provide devices for students to use.

\section{Table 1}

\begin{tabular}{|l|l|}
\hline Question & Solution \\
\hline $\begin{array}{l}\text { Where would the laptops be stored and } \\
\text { recharged? }\end{array}$ & $\begin{array}{l}\text { The Earthwalk laptop cart was the ideal place } \\
\text { for storage and charging. The unit also } \\
\text { included 24 backup ("sidekick") batteries } \\
\text { (one for each laptop) which are portable and }\end{array}$ \\
\hline
\end{tabular}




\begin{tabular}{|l|l|}
\hline & $\begin{array}{l}\text { easy to plug into a laptop-even while the } \\
\text { laptop is in use. }\end{array}$ \\
\hline $\begin{array}{l}\text { What backups would be in place if the } \\
\text { wireless is unavailable? }\end{array}$ & $\begin{array}{l}\text { Installing a special floor of electricity and } \\
\text { Ethernet wires was too expensive. Instead, the } \\
\text { university electricians installed additional } \\
\text { power outlets and Ethernet ports to the } \\
\text { periphery of the room and extra Ethernet } \\
\text { cords were added to the classroom budget. }\end{array}$ \\
\hline $\begin{array}{l}\text { How could multiple monitors be used by the } \\
\text { instructor and students to project and share } \\
\text { monitors and computers? }\end{array}$ & $\begin{array}{l}\text { The initial solution was to purchase several } \\
\text { wireless PC-to-TV adapters to project a } \\
\text { students' or instructors' screen to multiple } \\
\text { monitors. Warpia 120 devices were selected. } \\
\text { After the PC-toTV adapters did not work as } \\
\text { planned, the systems librarian investigated } \\
\text { screen mirroring options and chose the } \\
\text { Peerless HD Flow device. } \\
\text { Carts (with casters) were purchased for each } \\
\text { monitor to allow for mobility. }\end{array}$ \\
\hline $\begin{array}{l}\text { How can the library keep all of the } \\
\text { technology on the instructor's station wirefree } \\
\text { so the librarian can move the unit to the } \\
\text { middle of the classroom and still use the } \\
\text { technology? }\end{array}$ & $\begin{array}{l}\text { The systems librarian found suitable } \\
\text { Uninterruptible Power Supply (UPS) batteries } \\
\text { to add to the instructor's station, as well as to } \\
\text { one of the three flat screen monitors, so } \\
\text { librarians had the option to move the units to } \\
\text { accommodate each class. A small document } \\
\text { camera (ELMO) that connected via USB to } \\
\text { the instructor's laptop replaced the original } \\
\text { ELMO projection device. }\end{array}$ \\
\hline
\end{tabular}

The library received a Library Services and Technology Act (LSTA) technology grant, funded by the federal government's Institute of Museum and Library Services (IMLS) under the provision of the state's library. Along with matching funds from the library, the grant funded the purchase of the flexible furniture, laptops, laptop cart, and a document camera. The university already had licenses for various classroom software including Deep Freeze, MS Office, classroom management software, and virus protection; these programs were installed on the laptops. The library's dean secured money for a full renovation of the room, which included additional electricity, new carpeting, and paint.

\section{Implementation and Results}

For the librarians, the ideal electronic classroom would be both wireless and wire-free, meaning that, in addition to being able to use wireless technology, there would be no power cords of any kind to obstruct flexibility, collaboration, and active learning. Though many of the librarians' key needs were met, they failed to make all of these dreams a reality. Sometimes goals clashed with policies; other times, the goals were slightly ahead of the available technology. 


\section{Challenge 1: Wireless Authentication}

The first major hurdle was policy-related. Due to the "one-shot" nature of library instruction, librarians were unwilling to waste valuable class time as students logged into each device, a process that often resulted in problems and delays. The established workaround, which was also designed for community patrons and other library guests, was to have a generic login so that laptops could be started and logged in when students arrived in class. Unfortunately, the campus Information Technology (IT) department had a very restrictive wireless policy. Access for devices without domain user accounts were limited to only individuals with domain accounts. Accounts were required to be assigned to an affiliated individual; "non-person" accounts, such as those serving departmentally shared utilities like a a general email reference service, were restricted on the wireless system.

Other issues related to security had to be addressed as well. After many conversations (and demonstrations of various problems) with IT employees and administrators, librarians were able to create a policy and procedure specific to the e-classroom laptops. The solution involved restricting access of these laptops to only adjacent wireless ports around the classroom, authenticating based on the MAC address rather than a username, and creating a virtual private network for these devices. Students who brought their own devices already had necessary permissions to authenticate with their university ID and were able to use the wireless in the classroom as they would anywhere else on campus.

\section{Challenge 2: Wireless Display of Image to Multiple Devices (and the pixelation problem)}

The librarians decided to keep a large screen in front of the room, which meant there had to be a traditional projector to go with it. Contrary to expectations, the wireless PC to TV adapters that the library purchased for screen mirroring did not allow the presenter to simultaneously project a screen to both the projector and multiple monitors. The purchase was not a total loss, however, because the devices will still display one laptop to one monitor-allowing small groups to share their results with one another. Unfortunately, the devices require some setup time and only allow one PC-TV monitor connection at a time, so sharing screens is a manual process.

Wireless screen mirroring products are difficult to identify because it is easy to mistake multiple connections on the receiver device as being equivalent to running multiple devices in different locations in the room. Products such as Actiontech MyWirelessTV, IOGear Wireless HD digital kit, DVDO Air, and Rocketfish RF-WHD200 are designed for home entertainment systems; they have a similar mirroring process by streaming HDTV wirelessly so users don't have to run cable through their houses from the source. However, they do not send a signal to multiple devices wirelessly. Librarians needed to be able to project their computer screen to the traditional projector and to each monitor around the room. The new furniture configurations meant that students were seated at round tables; students would be facing in different directions rather than looking at one screen in front of the room.

The systems librarian identified a product to fit the library's needs: HD Flow from Peerless. This product uses paired transceiver/receivers and will work with up to four devices at one time to display a PCs image. We purchased four of the HDTV (HDS200-4) devices. In order to fully realize this solution, we also had to upgrade the projector (mounted to the ceiling) in order to accommodate the HDMI input. Given the classroom's laptop model and operating 
system (Window 7), there were limitations on what options we had to project the screen of the laptops. The HDMI ports did not work correctly with the HD Flow and we had to use the VGA ports for projecting. In investigating other possible solutions to wirelessly projecting display images, we discovered a possible solution using the Microsoft wireless display adaptor, but it only worked with Window 8.1, which was not an option nor was the university supporting Windows 10 at the time.

The HD Flow worked well for the first semester of use; librarians typically used it to project their laptop display to a screen (via the projector) and three monitors throughout the room. Occasionally, librarians would have to reset the device because it would lose the settings (VGA at the transceiver and HDMI for the receivers). Later in the year, librarians noticed some strange pixelation on the monitors and the projector when they tried to share their laptop screen with the projector and/or the monitors. The librarians started referring to it as "pixelation" because it looked much like a satellite signal in a rainstorm; the screen looked scrambled. One of our librarians described it as being in The Matrix!

To make matters worse, the pixelation problem seemed to occur only when the reference librarians had a classroom full of students - not when the systems or IT staff came to troubleshoot. Duplicating the issue without a room full of students became a real problem for identifying the source of the problem. The systems librarian developed a variety of theories including various types of wireless interference such as the wireless mouse or the students' personal devices.

Working from the angle of some sort of wireless interference, the systems librarian asked Campus IT to change the primary port for the wireless laptops used so that it would be different from the HDFlow in order to alleviate the wireless traffic. The HDFlow device itself had two different ports that could be switched between. Neither of these methods helped, nor did they allow the librarians to "catch" the problem as it occurred. Finally, the only sure solution found was to bypass the HDFlow entirely and go to a completely wired connections. The librarians were instructed to use the backup system of directly connecting the VGA connection to the single overhead projector, which quickly became the primary solution because it was reliable. Unfortunately, it also meant that the additional flat screen monitors couldn't be used in this configuration. After over a year of troubleshooting, the librarians simply could not use wireless technology as the primary means of delivering data to all of the displays. Quotes were acquired for running VGA or HDMI wired cabling to all the devices as well as upgrading the Extron control panel. Unfortunately, this meant giving up the goal of a truly wireless and wire-free active learning classroom; each display device would be tethered to the wall by both power and data.

The HDFlow system was replaced by directly wiring the instructor's station to the Extron Box and running HDMI cable to all three flat screen TVs in the room. Each TV was given an extra length of cable so they could be moved to the center of the room. Because they are now wired for data, there is no need for the Uninterruptible Power Supply Batteries. The HDFlow is now no longer the default connection. Fortunately, as mentioned in the literature review, the technology is finally catching up with dreams of wireless display. A recent upgrade to Windows 10 will allow exploration of options such as AirMedia.

\section{Challenge 3: A Flexible Instructor's Station with Classroom Control}


Because of the wireless display problem, the final solution required the instructor's station to be hardwired to the control panel in the front right-hand corner of the room. This meant that librarians were unable to move the instructor's station to the middle of the room if they wanted to project their screen via the projector or the flat screen monitors. This was disappointing; a major aspect of active learning classrooms like SCALE-UP is to take the "sage" off the "stage." Though librarians employ a lot of active and collaborative learning, they still conduct brief demonstrations and explanations that require sharing their screen - and they needed the hardware to be reliable.

In addition, while the instructor's station was a duplicate of the student laptops in many ways, there were some important differences. One of the software solutions used to control the use of student computers across campus was a product called SchoolVue 11 by CrossTec. This classroom management software is used in electronic classrooms with wired desktops to eliminate inappropriate technology use during teaching. This software can give the instructor station control of the student computers by freezing the screens, sending the instructor station desktop display to all the student machines, and distributing files and software. SchoolVue can even remotely control operation functions such as powerup and shutdown. Setting up, testing, and learning to use classroom management software in a wireless laptop environment was quite challenging. During the course of their teaching, the librarians used it very little and decided to remove it during the next software upgrade. Consequently, it can take some time before and after classes to turn on all the laptops by hand.

\section{Success 1: Layout and Furniture}

Probably the most instant and dramatic change was the replacement of the computer lab furniture with the half-moon tables on casters. The default classroom layout features six round tables; a layout similar to the SCALE-UP model. Students have ample surface space, even in large classes, and can easily collaborate in groups or pairs. The removal of the large desks and the ramps that covered the wiring allowed much more space for librarians and students to move about the room. Despite the fact that the instructor's station is now hardwired to the wall, librarians are able to spend much of their time milling about the room and acting as coach and guide, rather than lecturing at the front of the room. The seven whiteboards installed on the walls around the room have also been very handy for students to share results of projects or to brainstorm topics and keyword strategies.

\section{Success 2: Power Management}

The Earthwalk computer cart and charging stations have been very useful in our electronic classroom. While not in use, all of the laptops are stored - and can be locked - in the cart. The cart has a high efficiency charging station, eliminating the need for multiple AC adaptors or recharging time between classes while using a single power plug. With the additional sidekick batteries, this solution allows the 24 student laptops to be used all day long without returning them to the cart; there are many busy times during a semester when there are all-day, back-toback class sessions in the room.

The only downside is that, when the cart's power is on, the fans can be very loud. With the addition of a wired, wall-mounted programmable timer, this disruption was minimized; the cart charges all night and is powered off during teaching time. 


\section{Success 3: Wireless Access for Multiple Devices}

Though not a groundbreaking innovation, the wireless access was a significant improvement in the usability of this electronic classroom. The typical electronic classroom on campus still uses wired desktop PCs. Once the policy issues with automatic login were addressed, the wireless in the room worked well - even with large groups or classes. Two wireless hubs were installed in the room to make sure access was adequate for the number of devices in the room. Librarians have noticed that many students bring their devices to class, and these hubs in the room have been able to handle all the traffic in the room. Since the displays were directly wired, the librarians have seen no other wireless.

\section{Use of the Electronic Classroom}

Many of the successes and failures were discovered during installation, but more specifics was needed about what the librarians were actually using when they taught in the classroom. A survey was distributed to the nine librarians (including one of the authors of this article) who regularly teach in the electronic classroom. This survey was intended to gather details about classroom use and to assess librarians' overall satisfaction with the renovation of the classroom. The survey was not intended as a generalizable study; however, some of the results illustrate how different technology and equipment have been used in a practical setting. The respondents reported their experience teaching a total of 160 classes taught from August 2015 through the end of the academic year in May 2016. The librarians were allowed to fill out the survey more than once to report on classes as they taught them (i.e., some reported on their fall classes in December and their spring classes in early June) — resulting in fifteen completed responses.

Some of the results were not surprising. One hundred percent of respondents reported using the laptops and whiteboards. Most respondents reflected use of the plug-in backup batteries (when needed) and the use of the overhead projector. In contrast, only $54 \%$ of the respondents reflected use of the three TV monitors. Of the other technology in the room, none of the respondents reported using the DVD player or the ELMO document camera.

Eighty-seven percent (87\%) of responses reflected use of group work/collaborative learning. This use was defined in the survey as having students work in pairs or groups of three or more. Most respondents said they did not move the furniture, monitors, and the instructor's station because it was not necessary for their class plan, but several also reported that it "seemed like too much trouble." Certainly, the most "troublesome" furniture to move was the instructor's station, which ended up being hardwired to the wall, but moving tables or the monitors often was not.

A few responses reflected occasional problems with the wireless or malfunctioning laptops, but the overwhelming problem was the projector pixilation. Fifty percent of respondents reported this problem, though only one respondent reported having the problem after the hardwiring solution was implemented in September 2015. Respondents reported a few other problems including sound, monitor display, and changing from the instructor's laptop.

Table 2

\begin{tabular}{|l|l|l|l|l|l|}
\hline Question & $\begin{array}{l}\text { Strongly } \\
\text { disagree }\end{array}$ & Disagree & $\begin{array}{l}\text { Neither Agree } \\
\text { nor Disagree }\end{array}$ & $\begin{array}{l}\text { Strongly } \\
\text { Agree }\end{array}$ \\
\hline
\end{tabular}




\begin{tabular}{|l|l|l|l|l|l|}
\hline $\begin{array}{l}\text { The furniture allows for the activities I } \\
\text { plan for my library instruction sessions. }\end{array}$ & $6.67 \%$ & $0.00 \%$ & $0.00 \%$ & $53.33 \%$ & $40.00 \%$ \\
\hline $\begin{array}{l}\text { The furniture allows for the activities } \\
\text { and group work I plan for my library } \\
\text { instruction sessions. }\end{array}$ & $6.67 \%$ & $0.00 \%$ & $0.00 \%$ & $46.67 \%$ & $46.67 \%$ \\
\hline $\begin{array}{l}\text { The technology allows for the activities } \\
\text { I plan for my library instruction } \\
\text { sessions. }\end{array}$ & $6.67 \%$ & $6.67 \%$ & $13.33 \%$ & $66.67 \%$ & $6.67 \%$ \\
\hline $\begin{array}{l}\text { The technology allows for the group } \\
\text { work I plan for my library instruction } \\
\text { sessions. }\end{array}$ & $6.67 \%$ & $6.67 \%$ & $6.67 \%$ & $66.67 \%$ & $13.33 \%$ \\
\hline
\end{tabular}

Note: The intent of the survey was to gauge use of a specific classroom by teaching librarians, therefore the sample size was small $(n=9)$.

\section{Other Findings: Wireless and Electrical Backup Measures}

When planning for the classroom, the librarians built in backup measures in case the wireless access and backup batteries did not work as planned. Additional electrical outlets were added to the periphery of the room (adding them to the floor was not an affordable option). The tables were purchased with built-in plugs/receptacles, but because the tables had to be moved to the edges of the room in order to connect to power, librarians did not make use of those outlets; the useless outlets were confusing to students hoping to charge their personal devices, so the built-in power outlets were removed and the holes capped by grommets. As it turned out, the back-up batteries for the laptops were enough to supply power for the entire day; there was no need for wired backup.

In anticipation of problems with the wireless, additional Ethernet ports were added to the wall along with the electrical outlets. The systems librarian created backup kits made up of a switch and the needed cables to plug into the Ethernet wall ports. This also turned out to be an unnecessary measure; after the policy matters were addressed, the wireless access has worked well. However, the plug in ports have been handy for the systems staff, who often need a direct wired connection when conducting upgrades to the hardware.

\section{Conclusion}

Can an electronic classroom that both facilitates active and collaborative learning and has the technological bells and whistles of a hardwired classroom? The results of the classroom at X university were mixed. The laptops with backup batteries and the classroom layout allow for a flexible and wire-free setting for the students. More advanced functions such as sharing multiple screens still had strings - wires - attached. If the librarians were to give advice to a library planning their own classroom project, it would be the following.

- Though changing the overall learning environment from a computer lab setting to an active learning space is the ultimate goal, the ability to move furniture around is less important. The librarians found that their initial setup supported group work and allowed presenters and participants to move about the room, even for large class sizes. In addition, many librarians thought reconfiguring the room for each class was too much trouble, despite the fact that the furniture was designed to be moved around. 
- When faced with a room full of students, reliability trumps bells and whistles. Innovative technology is useless if it does not work efficiently and consistently.

- Simple low-tech features such as whiteboards and projectors are still very important in the electronic classroom. They can be used just as effectively--if not more so--than hightech visual display tools.

- Make sure to talk through all details of the plan with the campus IT department to ensure they are able to provide the support needed. These discussions should involve both technical details (types of software and hardware support) and overall technology security policies. As the librarians in the case study found, just because something is technologically possible doesn't mean that an IT department allows or supports it.

- Stay on top of changes in technology; though all display systems are hardwired at present, the librarians are aware of new features to explore in the future (such as a Windows upgrade and AirMedia).

Because the library needed the technology to be reliable, consistent and easy to set up, the librarians had to give up wireless display and screen sharing--and had to tether the instructor's station to the wall. Though this was initially disappointing, the majority of the librarians who teach in the room reported that they were able to incorporate active and collaborative learning into their instruction sessions, which was the ultimate goal. The key in an active learning classroom design is to always keep student learning at the center.

\section{References}

Baglier, T. and Caswell, T. (2016), "Destroy your classroom! Re-conceptualizing the instructor/student model in academic libraries", Journal of Library Administration, Vol. 56 No. 1, pp. 17-26.

Beichner, R.J., Saul, J.M., Abbott, D.S., Morse J.J., Deardorff, D.L., Allain, R.J., Bonham, S.W., Dancy, M.H., and Risley, J.S. "The Student-Centered Activities for Large Enrollment Undergraduate Programs (SCALE-UP) project”, Reviews in Physics Education Research, Vol. 1 No. 1, pp. 1-42, available at https://www.ncsu.edu/per/Articles/Chapter.pdf (accessed 1 June 2016).

Bonwell, C.C. and Eison, J.A. (1991), “Active learning: Creating excitement in the classroom”, 1991 ASHE-ERIC Higher Education Reports, ERIC Document: ED 336049, available at: http://eric.ed.gov/?id=ED336049 (accessed 14 December 2016).

Brooks, D.C. and Walker, J.D. (2010), "Making the case for space: Three years of empirical research on learning environments", EDUCAUSE Review, available at: http://er.educause.edu/articles/2010/9/making-the-case-for-space-three-years-ofempirical-research-on-learning-environments (accessed 14 December 2016).

Burr, D.F. (1971), What School Furniture Will Look like Tomorrow, ERIC Document: ED 048668, available at http://files.eric.ed.gov/fulltext/ED048668.pdf (accessed 14 December 2016). 
Chism, N.V.N. (2006), "Challenging traditional assumptions and rethinking learning spaces", in Oblinger, D.G. (Ed.), Learning Spaces, EDUCAUSE, pp. 2.1-2.12, available at http://net.educause.edu/ir/library/pdf/PUB7102.pdf (accessed 14 December 2016).

Clayphan, A., Martinez-Maldonado, R., Tomitsch, M., Atkinson, S., and Kay, J. (2016), “An inthe-wild study of learning to brainstorm: Comparing cards, tabletops and wall displays in the classroom", Interacting With Computers, Vol. 28, No. 6, pp. 788-810.

Dori, Y., and Belcher, J. (2005), "How does technology-enabled active learning affect undergraduate students' understanding of electromagnetism concepts?" Journal of the Learning Sciences, Vol. 14, No. 2, pp. 243-279.

Fink, D. (2013), Creating Significant Learning Experiences: An Integrated Approach to Designing College Courses, San Francisco, Jossey-Bass.

Finkelstein, A., Ferris, J., Weston, C., \& Winer, L. (2016), "Research-informed principles for (re)designing teaching and learning spaces”, Journal of Learning Spaces, Vol. 5, No. 1., pp. 26-40.

Gormley, C., Glynn, M., Brown, M., and Doyle, J. (2016),'Mobile learning spaces for a mobile generation: redesigning the classroom", Proceedings Of The European Conference On ELearning, pp. 239-248.

Hattie, J. (2009), Visible Learning: A Synthesis of Over 800 Meta-Analyses Relating to Achievement, London, Routledge.

Head, A.J. (2016), "Planning and designing academic library learning spaces: Expert perspectives of architects, librarians, and library consultants", Project Information Literacy: The Practitioner Series, available at http://www.projectinfolit.org/uploads/2/7/5/4/27541717/pil_libspace_report_12_6_16.pdf (accessed December 14, 2016).

McCullough, B. "The evolution of a flexible classroom", Proceedings of the 37th annual ACM SIGUCCS fall conference: Communication and collaboration, Association for Computing Machinery (ACM), New York, pp. 305-308.

McGill, M., Williamson, J., and Brewster, Stephen A. (2014), "Mirror, mirror, on the wall: Collaborative screen-mirroring for small groups", Proceedings of the ACM International Conference on Interactive Experiences for TV and Online Video, Association for Computing Machinery (ACM), New York, pp. 87-94.

Oblinger, D.G. (Ed.), Learning Spaces, EDUCAUSE, available at http://net.educause.edu/ir/library/pdf/PUB7102.pdf (accessed 14 December 2016).

Soderdahl, P.A. (2011), "Library classroom renovated as an active learning classroom," Library Hi Tech, Vol. 29, No. 1, pp. 83-90. 
Svinicki, M. D., McKeachie, W. J., Nicol, D., and McKeachie, W. J. (2014), McKeachie's Teaching Tips: Strategies, Research, and Theory for College and University Teachers. Belmont, CA, Wadsworth/Cengage Learning.

\section{Appendix: Vendors, Equipment and Technology Referenced in this Article}

Actiontech MyWirelessTV (https://www.actiontec.com/)

AirMedia (http://www.crestron.com/microsites/airmedia-mobile-wireless-hd-presentations)

Airplay (https://support.apple.com/en-us/HT204289)

CrossTec (http://www.crosstecsoftware.com/schoolvue/)

DVDO (http://dvdo.com/products/\#product-section-01)

Elmo Document Camera https://www.cdwg.com/shop/products/Elmo-MO-1-Visual-Presenterdocument-camera/2873993.aspx\#PO

Extron (http://www.extron.com/product/prodtype93.aspx?t=medialink)

Google Chromecast

(https://www.google.com/intl/en_us/chromecast/?utm_source=chromecast.com)

IOGear (https://www.iogear.com/solutions/av/)

Peerless HD Flow (http://www.hdflow.com/Products/index.html)

Rocketfish (https://www.rocketfishproducts.com/pdp/RF-WHD200/1254005)

StreamHD (http://www.warpia.com/products)

WiFi EZCast (http://www.wifiezcast.com/index_en.html) 